https://helda.helsinki.fi

\title{
Intentionality in Medieval Augustinianism
}

Silva, José Filipe

2018

Silva , J F 2018 , ' Intentionality in Medieval Augustinianism ' , Phänomenologische

Forschungen , pp. 25-43 . https://doi.org/10.28937/1000108200

http://hdl.handle.net/10138/304826

https://doi.org/10.28937/1000108200

acceptedVersion

Downloaded from Helda, University of Helsinki institutional repository.

This is an electronic reprint of the original article.

This reprint may differ from the original in pagination and typographic detail.

Please cite the original version. 


\title{
Intentionality in Medieval Augustinianism
}

\author{
José Filipe Silva*
}

Abstract

Since Brentano, intentionality has become a key feature of debates within philosophy of mind and epistemology, expressing the directedness and the aboutness of mental acts. In recent decades, a wide range of studies has showed the historical background of this concept beyond the historical sources Brentano himself acknowledged. Augustine (354-430) has been prominently mentioned in some of these studies, the focus of which has mostly been on the aboutness aspect, that is to say on how this mental event is about a particular thing. I think there is yet another side to Augustine's account of intentionality and this is the general undetermined directedness of the soul to the world, which results from its way of being in the body. Such an account commits Augustine to a certain account of perception, one which does not accept that we are causally acted upon by material things, but rather suggests that we are the agents, and causes, of our own cognitive acts. This is true not only of Augustine but also of many medieval authors within the tradition of Augustinian philosophy of perception. The focus of this article is how this position is elaborated in some thinkers of the Middle Ages, namely Henry of Ghent (1217-1293) and Peter John Olivi (12481298).

\footnotetext{
* (jose.pereiradasilva@helsinki.fi) Associate Professor in Medieval Philosophy, Department of Philosophy, History, Art and Culture Studies, Unioninkatu 40 A, 00014 University of Helsinki. The author would like to acknowledge the funding from the European Research Council under the grant agreement n. 637747. The author would also like to thank the audience in Würzburg for their comments, especially Jörn Müller, Michela Summa, Therese Cory, Dag Hasse, and Gianfranco Soldati.
} 
Since Brentano, the story goes, intentionality has been a key feature of debates within philosophy of mind and epistemology, expressing the directedness and the aboutness of mental acts: my perception is of this yellowish thing, my thought is about a glass of white Silvaner wine. In recent decades, this picture has gained in complexity, with a wide range of studies showing the historical background of this concept beyond the historical sources Brentano himself acknowledged. Augustine (354-430) has been prominently mentioned in some of these studies. Yet, their focus has mostly been on the aboutness aspect, that is to say on how this mental event is about a particular thing. I think there is another side to Augustine's account of intentionality and this is the general undetermined directedness of the soul to the world, as the result of its way of being in the body. Such an account, which I have explored in detail elsewhere, commits Augustine to a certain account of perception, one which does not accept that we are causally acted upon by material things but are the agents, and causes, of our own cognitive acts. This is true not only of Augustine but also of many medieval authors within the tradition of Augustinian philosophy of perception. The focus of this article is on how this is elaborated in some of these thinkers and in their works.

This article is divided into two main sections, with the second divided further into two sub-sections. In the first, I briefly discuss what I take to be the core of Augustine's view on attention and intentionality, notions I take, unsurprisingly, to be at the center of his theory of cognition. This is not intended to be either comprehensive or exhaustive. Rather, it aims to provide enough background information for the use that later Augustinians will make of these Augustinian ideas. The second part of my paper concentrates on precisely how Augustinian ideas on intentionality applied to cognition were developed in the later stages of the medieval period, and for this I will focus in subsection II.1 on the work of Henry of Ghent (1217-1293) and in subsection II.2 on Peter John Olivi (1248-1298). Again, my intention here is not to be comprehensive, as much work remains to be done on this strand of thought. My aim here is to suggest one way of approaching it. 
The structure of the argument is as follows: Augustine argues in several places that perception is defined as the soul attending to the affections of the body because the soul cannot be directly affected by material things, as this would go against the basic ontological hierarchy of the world. ${ }^{1}$ In cognition, the soul is the agent in its action of focusing its attention on the world. That being the case, it is difficult to see how we can actually come to know particular things in the world - in other words, what explains our attending to this rather than that object? - because Augustine's account seems to explain only how the soul attends to the body rather than accounting for how it attends to any particular thing affecting the body. My suggestion is that medieval Augustinians develop this theory by drawing the distinction between (a) attention to the body and its well-being as the general principle of operation of the soul, and (b) attention to particular external things that affect it as a determinate aspect of this general attention to the body. The soul is directed to the body as a whole as the result of its being wholly present in the body, but it directs its attention to a particular thing according to the affection of the body it cares for.

In some sense, since this makes it look as if the Augustinian soul merely reacts to the affection caused by the external thing, the act of cognition seems to be caused by the external thing, and this is precisely the point Augustine wished to argue against. Olivi will object to this passive account of the soul in his critique of the so-called excitation theory of perception. However, Olivi's criticism is unwarranted because it overlooks the primary level of attention, that is, the intentionality or directedness of the soul towards the body, which is prior to any particular instance of the body being affected. Now, I cannot pretend the arguments of these historical figures are as straightforward as I have just sketched, but the arguments are there. My job is to outline what I take to be the necessary steps in the argument.

\section{Augustine on vital attention}

\footnotetext{
${ }^{1}$ The only way he admits bottom-up causality is in the form of resistance, when the soul fails to impose its ruling on the body.
} 
At the beginning of his work On the Trinity, Augustine remarks that ,[w]e must adjust ourselves to this weakness" that comes from our inclination and familiarity with corporeal things, ${ }^{2}$ by which he means becoming acquainted with the way our perceptual contact with the world takes place. And that of course means to give center stage to the notions of intention and attention, as constitutive of our experience of the world, which is illustrated in the following passage:

„Yet, as I have said, our familiarity with bodies has become so great, and our intentio has projected itself outwardly with so wonderful a proclivity towards these bodies, that when it has been withdrawn from the uncertain realm of bodies and fixes its attention on the much more certain and more stable knowledge of the spirit, it again takes refuge in these bodies and seeks rest there from the place where it drew its weakness. “3

Here the two terms come close to what we take them to mean in contemporary everyday language, that is, ,intention ${ }^{\star}$ as intending or aboutness and, attention' as focus or concentration (like a spotlight) on a particular feature or aspect of whatever reality is taken as the object of a given mental state. In the following chapter of the same work, where he explains the process of perception in more detail through the imagery of the outer man (the part of the human cognitive system that accounts for our interaction with the external world), Augustine points out that intentio is the power of the soul that „fixes the sense of sight on the object that is seen as long as it is seen." As long as the external thing is present, the intentio of the soul is hooked onto it because that external thing is the cause of an affection of the body the soul informs. This is the point of departure for Augustine's famous definition of perception as ,,an affection of the body that by itself does not go unnoticed by the soul. ${ }^{\prime 4}$ This is taken to mean that in any perceptual experience, the soul is not acted upon by the

\footnotetext{
${ }^{2}$ Augustine: De Trinitate (hereafter DT) ed. W. J. Mountain with the assistance of F. Glorié. Turnhout 1968. 11.1.1. trans. McKenna. In Augustine: On the Trinity, books 8-15. Cambridge 2002. 61 (I use this translation, except when otherwise noted).

${ }^{3}$, ,...] tamen, ut dixi, tanta facta est in corporibus consuetudo, et ita in haec miro modo relabens foras se nostra proicit intentio, ut cum ab incerto corporum ablata fuerit, ut in spiritu multo certiore ac stabiliore cognitione figatur, refugiat ad ista, et ibi appetat requiem unde traxit infirmitatem." DT 11.1.1./On the Trinity. 61, translation modified.

${ }^{4}$ „Sensus est corporis passio per seipsam non latens animam“, De quantitate animae, ed. W. Hörmann. Vienna: Verlag der österreichischen Akademie der Wissenschaften 1986. 30.59. See also De musica liber VI, ed. and transl. Martin Jacobsson. Stockholm: Almquist \& Wiksell 2002. (DM, hereafter) 6.5.10.
} 
body (or the external thing) but acts on „the reactions of the body“ and it is the soul's awareness of these actions that properly constitute ,perceiving“. ${ }^{5}$ And this should not take us by surprise because „,it is not strange that the soul, which acts in the mortal flesh, perceives the reactions of bodies. ${ }^{\text {“6 }}$ Perception depends on the soul's active attending to the presence of the thing (via its form) ${ }^{7}$, in ${ }^{6}$ the body, but this attention is present before the perception of an external thing, since sense belongs to the nature of a living thing. ${ }^{8}$ In other words, Augustine is noting that the soul's intending is already present in the sentient being prior to any particular encounter in a way that is not cognitive, but rather pre-cognitive. And this, I claim, is the result of the soul being the way it is, in other words, of maintaining a particular way of being related to the body, which Augustine describes as being wholly in each part of the body (that is, it is in all parts of the body as one and the same subject). ${ }^{9} \mathrm{I}$ take this to mean that it is prior in nature, ${ }^{10}$ but also prior in operation: if there is no attention paid to the body, then there will be no attention paid to the thing that is the object of that particular sense experience.

Such an account is at the heart of a major tension in Augustine's thought, since although the inclination to the sensory world is problematic, as it implies turning away from a higher contemplative life, sense perception is viewed in a positive manner in that it allows us a primary

\footnotetext{
${ }^{5}$, ,...] uidetur mihi anima, cum sentit in corpore, non ab illo aliquid pati sed in eius passionibus adtentius agere, et has actiones [...] non eam latere, et hoc totum est, quod sentire dicitur." DM 6.5.10.

${ }^{6}$ „Ergo animam in carne mortali operantem passionem corporum sentire non mirum est.“ DM 6.4.7.

${ }^{7}$ The affection of the body by an external thing is the reception of the form of the sensible thing (the external object) in the sense organ. In the case of the distal senses, such as vision, the object is made present to the perceiver by impressing its sensible form, also called species, in the perceiver's sense organs and/or powers. (As we shall see, whether this reception takes place in the sense organs and powers or in the sense organs only is a matter of contention). The sensible form or species represents the property of the object that is proper to that sense modality, like color to sight.

${ }^{8}$,the sense that was already in the living being, even before it saw what it could see when it came upon something visible“, DT 11.2.2, 62 (,,sensus autem qui iam erat in animante, etiam priusquam uideret quod uidere posset cum in aliquid uisibile incurreret", 335). Augustine makes the same point in many ways; for instance, when in DM 6.5.11 he remarks that the „same soul, which prior to this sound [just sounding] gave life to the body of the ears in a vital movement in silence“ (,,animam illam, quae ante istum sonum uitali motu in silentio corpus aurium uegetabat“. Ed. cit. 30-1). On this see José Filipe Silva: Perceptiveness. In: Proceedings Aristotelian Society Supplementary Volume (2017, forthcoming).

${ }^{9}$ „Tota igitur singulis partibus simul adest, quae tota simul sentit in singulis. Nec tamen hoc modo adest tota, ut candor vel alia hujusmodi qualitas in unaquaque parte corporis tota est.“ De immortalitate animae. In: Jacques Paul Migne (ed.): Patrologia Latina. Paris 1877, vol. 32. 16.25, 1034.

${ }^{10}$ „For if the sense were not within us even before the visible things were presented to our sight". DT 11.2.2 (,Nam sensus et ante obiectum rei sensibilis nisi esset in nobis non distaremus a caecis“". 335).
} 
grasp of the world created by God. Moreover, perception is essential for us to survive in the physical world and this needs to be explained by recourse to the mode of presence of the soul in the body that follows from the soul's definition as the principle of life and the ruler and governor of the body. ${ }^{11}$ The core of my suggestion is that we tend to emphasize what gives the perceptual experience the content it has, rather than considering what makes the experience - any particular experience - possible. And it is by focusing on the latter aspect, rather than on the former, that Augustine has something original to contribute to debates concerning intentionality. I don't think mine is a completely novel suggestion, ${ }^{12}$ but it is a necessary suggestion in order to make sense of Augustine's account in the face of his commitment to ban bottom-up causality in explaining perception. For Augustine, an account of perception does not start (or is not even properly described) with the soul reacting to the stimulation of the sense organs by paying attention to an affection they undergo; instead, for Augustine, I argue, it is the attention directed to the external world prior to the stimulation of the sense organs that makes this stimulation epistemically relevant and ultimately what makes perception possible. ${ }^{13}$ Intentio then means, first of all, a basic sort of attention that is directed to the body that follows from the soul's role as the ruler and principle of life, and that I would like to call 'dispositional attention'. Once the sense organs have been affected by the external thing, the ,will, which continuously moves the eye to be informed here and there and unites it when informed with its object" ${ }^{14}$ keeps the object in focus, as the end term of the cognitive act.

\footnotetext{
${ }^{11}$ „Therefore, the soul dominates the now mortal and frail body with great difficulty and attention." ("Quodcirca mortali iam et fragile cum magna difficultate atque attentione dominatur."), DM 6.5.14, ed. cit, pp. 34-5. It is remarkable (and often neglected) that Augustine states in DM 6.4.7 that the body has "a beauty of its own kind and by that very fact it commends adequately the excellence of the soul“ (,habet sui generis pulchritudinem et eo ipso dignitatem animae satis commendat". Ed. cit. 20-1), introducing thus a proportionality of excellence between the human body and soul which would even be better if it had not been marred by Original Sin".

${ }^{12}$ On this, see especially Ludwig Hölscher: The Reality of the Mind. London 1982. 96.

${ }^{13}$ On this distinction, see José Filipe Silva: Augustine on Active Perception. In: José Filipe and Mikko Yrjönsuuri (eds.): Active Perception in the History of Philosophy. From Plato to Modern Philosophy. Dordrecht 2014; and José Filipe Silva: Perceptiveness (forthcoming).

${ }^{14}$ DT 11.4.7, transl. McKenna. 68.
} 
Therefore, when the body - or part of it - is affected, the soul perceives in the body. ${ }^{15}$ Further evidence for this is that when there is an impediment in the bodily organ, ${ }^{16}$ the intentio remains as the property of the soul's relation to the body:

„the very effort itself indicates that, though the bodily sense has been removed, the attention itself could neither perish nor be diminished.“17

The attention to the body is there; it simply does not direct its focus to any object in the external world anymore because it cannot receive the proper affection in the organ. The first type of intentionality characterizes the soul's mode of being in the body, prior to and underlying any perceptual experience. But it does not simply underlie; rather, it is from this mode of presence, that is, from the body that lives, that ,sensation proceeds“. ${ }^{18}$ In this sense, intentionality is a primitive feature of living beings that are also cognitive.

Medieval Augustinians will take these two core ideas as the starting point for their theories of perception; that is, the idea that sensation originates or has as its cause that which is responsible for making the body living - the soul - and the idea that this is possible because the soul is fitted together' with the body: as wholly in each part, as the internal life principle of animated bodies, with each power in appropriate (,fitting“) bodily sense organs.

\section{Medieval Augustinians on the Philosophy of Perception}

\section{II.1. Henry of Ghent on the primary agent of sensation}

The first author I would like to consider is Henry of Ghent (1217-1293), who examines in some detail the activity-passivity dichotomy with respect to the soul's cognitive acts. At stake is the

\footnotetext{
15 “... sentit in corpore“, DM 6.5.10.

${ }^{16}$ Both in the case of blindness (DT 11.2.2) or in the case of deafness (DM 6.2.3), the aspect/power of the soul that Augustine refers to as attention remains even when the sense organ cannot (or does not) take any input from the external world. Whether the power responsible for this attention in DT 11.2.2 corresponds to the "uis quasi iudiciaria" Augustine talks about in DM 6.2.3 or is a different cognitive power of the soul remains to be investigated.

${ }^{17}$ DT 11.2.2, trans. McKenna 63.

${ }^{18}$ DT 11.2 .3 (see above)
} 
question of whether the soul is the total cause of actual cognition or whether perception is the result of the causal action of certain objective features or properties of things that actualize a perceiver's sensory powers by informing the appropriately disposed physical sense organs. According to this latter model, to perceive is „to be moved and affected“ (sensus autem in moveri aliquid et pati accidit, 416b33) as expressed in Aristotle's De anima, the key source for understanding sensation. ${ }^{19}$ In this model, the sensible thing elicits actual sensing by impressing its likeness (similitudo) on the sense. That being the case, everything the perceiver is able to perceive is dependent on that causal efficacy and on the successful transmission of this information. We have just seen arguments against this description, founded on the idea that the soul has an inherent spirituality that cannot be reduced (in the medieval sense of actualization, or being brought about) to the contribution of a material thing. For Augustine, the role of the object is not to bring about a change of state in the perceiver's cognitive powers - those are self-caused - but to determine that the content of the perceptual act is about that particular present object (exhibiting that property/qualitative feature). In question 5 of his Quodlibet XI, Henry of Ghent references two main tenets of medieval epistemological Augustinianism, namely: the notion of cognitive operations (i) as vital acts and (ii) as immanent acts. ${ }^{20}$ Since cognitive acts are of the kind that do not transcend the cognitive agent, they must originate in the agent's cognitive power or the soul acting through the power. These two aspects can be joined into what I am calling the ,principle of equipollence':

[PE] In animals, the principle of life is the principle of cognition and as such its operations cannot but be internally efficiently caused.

\footnotetext{
${ }^{19}$ Cf. Thomas Aquinas, Sentencia libri de anima. In: Opera Omnia XLV.1. Rome-Paris: Commissio Leonina-Vrin 1984. c. 10, 107. Aquinas interprets this, somewhat tautologically, as "to sense [is] to be affected because the action of sense takes place in its being affected." "Vocat autem sentire passionem, quia actio sensus in paciendo fit", Sentencia libri de sensu et sensato. In: Opera Omnia XLV.2. Rome-Paris: Commissio Leonina-Vrin 1985. c. 1, 12.)

${ }^{20}$ Cf. Augustine, $D T 10.5$ and DM VI.5.9-12.
} 
This principle is based on an argument for the ,naturalism' of cognition, which includes two steps. The first is to claim that cognitive acts, as sensation, are vital acts. ${ }^{21}$ The second is to claim that vital acts are immanent acts, or those that do not go beyond what is possible for the agent's species. Vital (= cognitive) acts cannot be caused by non-living things because this would exceed their ontological level. Therefore, the argument concludes, cognitive operations as vital acts must be caused by the soul of the perceiver. ${ }^{22}$

This must be - and is - clearly distinguished from the case of something being heated by an external fire because that level of interaction is between two things lacking life, whereas cognition (sensation or intellection) is a vital operation, thus - in contrast to heating - is internally caused. ${ }^{23}$ Henry goes on to say that explaining cognition, especially perception, requires that one attribute to the soul the formation of images of external things in their presence to the physical senses, just like Augustine proposed in his De musica. ${ }^{24}$

As to the presence of the thing external to the bodily sense organs, Henry talks about alteration but classifies this into three kinds: the first happens when something changes into the contrary quality, such as takes place in the case of heating. The second is the change by which something acquires the disposition necessary for its operation; this is the alteration that takes place in the sense organs. The third is the change whereby something is elicited to the operation that is proper to itself, and

\footnotetext{
${ }^{21}$ „Agens per se operationem vitalem non est nisi viuum, quale non est aliquid extra“ Henricus a Gandavo, Quodlibeta. Venice 1608, Quodlibet XI, question 5 (Q.XI.5, hereafter), f. 195ra.

22, ,Nullum agens per se elicit actionem quae transcendit suam speciem, quia omnia actio est proportionalis agenti, sed actio vitalis, cuiusmodi est sensatio, aut intellectio, transcendit speciem omnis non viui in nobilitate, quia est nobilissima operatio: ergo est nobilissimi agentis cuiusmodi non est nisi vivum, quia non est aliquid extra existens, sed intra tantum; ergo etc.“, (Q.XI.5 195ra.). For Henry on causality and intellectual cognition with remarks on sensation, see Martin Pickavé: Causality and Cognition. An interpretation of Henry of Ghent's Quodlibet V, q. 14. In: Gyuola Klima (ed.): Intentionality, Cognition, and Mental Representation in Medieval Philosophy. New York 2015. 46-80.

${ }^{23}$ „Sicut actio calefaciendi attribuitur calido, sic \& actio viuendi viuo: tale autem non est aliquid extra“, Q.XI.5, f. $195 \mathrm{ra}$.

${ }^{24}$ „Nullius passionis sensibilis causa est natura corporalis, sed anima format eam in seipsa ad praesentiam illius, ut dicit August. in 6 Musicae.“, Q.XI.5, f. 195ra.
} 
this is the case of the sensory power. ${ }^{25}$ Henry explains that the sensory power has an internal disposition to be elicited into operation, thus being caused by itself. ${ }^{26}$

Henry further qualifies the way a power is able to bring itself into operation by making a distinction between motion or change (motio), which applies to the first type of alteration, and operation (operatio), which applies to the last one. ${ }^{27}$ Whereas the first kind of change is a case of transient action in which the motion is ordered to an end that is not in the acting thing but in another, in the case of an operation, it has its end in the perfection of the agent (/subject) itself. Acts of sensation, as vital acts, are of the latter kind and are not as such motions or changes but operations, according to Henry's classification. ${ }^{28}$

Created things, however, cannot have these dispositions for action in an absolute sense because this would entail being able to bring themselves into operation at will, without any motivating or triggering circumstances. It is on this issue that Henry dwells next. In his account, the perceiver has what he calls substantial dispositions in the sense that he/she is endowed with cognitive powers informing appropriate sense organs; but it must acquire the accidental dispositions. These are the result of the action of the external thing upon the sense organs, by means of which the power is „excited and inclined and determined to the act with respect to a particular object ${ }^{\text {‘2 }}$, of which the sensible species in the physical organ is a sign. Once more he insists that when the act is realized, constituted by the power, organ and species, it is an immanent act (actio manens), meaning that it obeys the aforementioned principle of equipollence.

\footnotetext{
${ }^{25}$ Q.XI.5, f. $195 \mathrm{ra}$.

${ }^{26}$ „Est autem alia alteratio sensitiui [than the one taking place in the organ of sense, in ipso organo sentiendi] principaliter in ipsa vi sensitiua, quae in ipsa est inclinatio quaedam ad actum operationis suae eliciendum“. Q.XI.5, f. 195rb.

${ }^{27}$ Q.XI.5, f. $195 \mathrm{rb}$.

${ }^{28}$,Operatio autem est actus, siue dispositio perfecti, secundum quod est perfectum \& non ordinatur ad aliud, sed est finis \& perfectio vltima eius, cuius est. Actiones autem vitales, quae sunt sensatio, \& intellectio, non sunt mutationes, aut motus, sed sunt proprie operationes sensus, \& intellectus; \& habent rationem actionis manentis in agente [...] non autem transeuntis in aliud“". Q.XI.5, f. 195rb.

${ }^{29}$,secunda autem immutatio eius est a sensibili secundum quod speciem suam immittit in organum [...] quia talem operationem, virtus sensitiva in organo existens non elicit, nisi excitata, \& inclinata, \& determinata ad actum respectu determinati obiecti, quas species existens in organo agit per virtutem eius, a quo processit in vim sensitiuam, cuius signum est, quod cum ipsa fuerit impedita magno impulsu debet excitari, ut actum suum eliciat"“. Q.XI.5, f. 196ra.
} 
Drawing heavily on Augustine's account of the process of perception in De Trinitate (11.2), Henry makes a clear separation between the causal (instrumental) role of the object in bringing to the sense organ the species that represents it, which is called vision, and the role of the cognitive power, which he calls a „primary agent"; the gist is that only the operation of the power is properly called sensation. ${ }^{30}$ Augustine, he says, ,names that intention of the soul causally because it is by means of it that the senses of the soul are turned to the objects to be perceived. ${ }^{\text {(331 }}$

The object generates or causes its own likeness in the organ in the form of the mentioned sensible species, whereas the soul is the agent of the cognition of the external thing via this likeness (this expression should not be taken as commitment to an epistemic claim of indirect perception but simply that its presence is a necessary condition for the perception of the external thing which it represents). ${ }^{32}$

Henry ends by pulling his punch, that is, by strengthening the notion of sensation as an operation of a living thing qua living on the one hand, ${ }^{33}$ while on the other hand recognizing that, although sensation is not passive, it does include two aspects of passivity: first, the reception of the likeness (or species) of the thing in the sense organ and second, the inclination of the sensory power to perceive the external thing that is determined by the presence of the object. Perception has thus an internal efficient cause and an external determination that is preceded by the power's natural disposition to operation. Henry retains two key ideas from Augustine: first, the understanding of

\footnotetext{
30 ,agens principale est vis animae inclinata; agens autem instrumentale est organum informatum specie“. Q.XI.5, f. 195vb. Martin Pickavé rightly emphasizes Henry's distinction between the reception of the species in the sense organ and the act of sensation; he does not however elaborate on the connection between cognitive acts and vital acts. Martin Pickavé: Causality and Cognition. 57-62. Because of this he doubts the Augustinian influences on Henry's thought, despite asserting that ,there is not a single passage in which he [i.e. Henry] calls them efficient causes of cognitive acts“" (see footnote 93, page 77 reference). It should be clear by now that I take this influence (and the cognitive-vital act connection) to be essential to explain his view.

31 „Vocat autem August. illam animi intentionem causaliter, quia per ipsam sit sensus animi intentus ad obiecta percipienda.“"Q.XI.5, f. 195va.

${ }^{32}$ On the issue of species as representations, see Jerome V. Brown: Sensation in Henry of Ghent: A Late Mediaeval Aristotelian-Augustinian Synthesis. In: Archiv für Geschichte der Philosophie 53/3 (1971) 238-266.

33 ,Sic ergo visio, \& universaliter sensatio actio est viuentis secundum quod est viuens, quae est operatio non motus, neque alteratio, nisi extendendo nomen alterationis, vt dicitur secundo de anima, \& non dicitur sensatio passio, nisi quia sine passio ne aliqua sensus informatus \& dispositus sentire non potest.“Q.XI.5, f. 195vb.
} 
perception as consisting in the immanent act of a living cognitive being; second, the refusal to make perception reliant on inward efficient causation that would go beyond determination of content.

\section{II.2. Peter John Olivi on undetermined and determined intentionality}

A radical development of this theory is found in the Franciscan Peter John Olivi (1248-1298). Olivi developed his theory of cognition in contrast with the basic tenets of the Aristotelian account, which, according to him, is grounded on the following claims: ${ }^{34}$

(i) all apprehension involves the assimilation of the cognitive subject to the object cognized

(ii) everything that is received is received according to the manner of the recipient

(iii) the actualization of the power's potentiality requires the action of something that is in actuality, e.g. sight is actualized by color.

Olivi accepts (i)-(ii) but rejects (iii). There are two main kinds of reason why he does so. First of all, for Olivi, the cognitive subject - the soul - is constituted by a spiritual matter, here meaning that it is capable of change and receptivity and form, whereas the sense organ is corporeal matter informed by the soul (or the soul via a power). So - the argument goes - if mediating the contact between object and sense power are forms (called 'species'), then these have either corporeal or spiritual being. If they have corporeal being, as it befits their origin, they can act on the organ but not on the sense power because spiritual matter (of which the soul is constituted) ,is not receptive of corporeal forms“. If, on the other hand, these forms have spiritual being - leaving aside for now the issue of created material things producing spiritual effects, thus effects that are superior to their causes in the scale of being - then it is difficult to see how these could be received in the sense organs because „,corporeal matter [is not] receptive of spiritual forms““ 35

A further argument concerns the representational power of the species. As an accident, the species

\footnotetext{
${ }^{34}$ Cf. Peter John Olivi: Quaestiones in Secundum Librum Sententiarum. Florence: Ad Claras Acquas: Ex Typographia Collegii S. Bonaventurae 1924 (QiniiS, hereafter), question 72, 1-2; 13-14; see also QiniiS 58. 394-95.

35, ,...] quia materia spiritualis non est capax formarum extensarum et corporalium nec materia corporalis formarum spiritualium.“ Peter John Olivi. QiniiS 72.12.
} 
would be ontologically inferior to the object which generated it and which it purports to represent and is therefore admittedly incapable of representing it. On the other hand, if the species has natural being, it would be perceived rather than the thing it purportedly represents. ${ }^{36}$ Furthermore, if there is a sequence of species throughout the medium up to the sense organs, all that the last species in the series would represent is the previous one in the series, not the originating object. ${ }^{37}$ Finally, the species do not represent the space between the object and the perceiver because the object is outside this intermediate space; but in that case the object would not be perceived as being at a distance (ut distans) from the perceiver. ${ }^{38}$ Thus, the nature of the species defies its purpose by veiling the access to the external thing (velaret rem) ${ }^{39}$ and should not have any place in the explanation of perception. The dismissal of the species doctrine in Olivi is the first step in denying any form of bottom-up causality - the idea that corporeal things can act upon the soul $-{ }^{40}$, a view he explicitly associates with Aristotle and his followers, who claimed that the soul is acted upon by external physical objects through the exercise of the object's power. ${ }^{41}$ This is a point frequently made in the relatively extensive literature on Olivi, but the same is not true of the following argument. According to Olivi, the action of the impression of the external thing on the senses is either

\footnotetext{
${ }^{36}$ QiniiS 73. 87. Olivi refers to some (quidam) who hold the existence of two kinds of species, those having natural being (esse naturale et sensibile) and those having intentional being (esse intentionale et spirituale). He explicitly denies that such a spiritual species could be issued from a corporeal thing and inform a natural body, like the medium and the organ. He also adds that according to some, to have 'intentional being' simply means to be insensible (i.e. not perceptible). The latter view is to be found e.g. in Roger Bacon: Perspectiva. In: David C. Lindberg (ed.): Roger Bacon and the Origins of Perspectiva in the Middle Ages. Oxford 1996. I.6.3, 83; and Roger Bacon: De multiplicatione specierum. In: David C. Lindberg(ed.): Roger Bacon's Philosophy of Nature. Oxford: Clarendon Press 1983. III.2, 193. On the other hand, no corporeal species can represent a thing (,nulla species corporalis in sensu existens potest repraesentare rem“. QiniiS 74.123).

37 „Item ad primum, species influxa prius et fortius et magis proprie et conformius repraesentabit speciem a qua immediate gignitur quam aliam. Sed ab obiecto distanti non potest fieri species in visu nostro nisi per aliquam genitam in medio. Ergo prius et fortius repraesentabit illam speciem quam illud obiectum." QiniiS 73. 84.

${ }^{38}$ „Ergo per speciem obiecti praedicti non videbitur quantitas seu distantia spatii intermedii ac per consequens nec obiectum videbitur ut distans ab ipso vidente.“ QiniiS 73.85.

${ }^{39}$ QiniiS 58. 469

${ }^{40}$,,anima nullum influxum directe recipit a corporibus vel ab obiectis, in quantum obiectis“ QiniiS 74. 108.

41 „Prima est Aristotelis et sequacium eius dicentium quod in spiritum corpori formaliter coniunctum agunt corpora et corporalia obiecta non solum per modum colligantiae nec solum per modum termini obiectivi, immo etiam per simplicem et impressivum influxum." QiniiS 72. 13. On this, see Juhana Toivanen: Perception and the Internal Senses. Peter of John Olivi on the Cognitive Functions of the Sensitive Soul. Leiden 2013.
} 
(a) a cognitive action or

(b) the effective source of a cognitive action or

(c) an action that excites the cognitive power to a cognitive act. ${ }^{42}$

It cannot be (a) because, he says, seeing is an action, whereas the object is passively seen. To see is a cognitive act and thus a vital act of the kind that only living things have, not objects or species. ${ }^{43}$

Likewise (b) is false on the same grounds, because the principle or source of knowing is founded upon the principle of being a living thing, which means that the cause of a particular perceptual act must be found in the operative principle - i.e., the power - rather than in its end-term, the object. In other words, the source of the production of the cognitive act is the power rather than the object or its species. ${ }^{44}$ (I shall return to this point later). Option (c) is wrong in a general sense but right in a qualified one as will become clear in what follows.

Olivi argues against the view found in some of his contemporaries that the object acts upon the senses, exciting the soul to action, described in his own words as ,the influx from the body to the spirit as an action that excites the [cognitive] power to its cognitive act". ${ }^{45}$ Olivi rejects this view because, if external things have the power to trigger the soul to make a representation (an internal species or similitude) of the triggering cause, this would still qualify as the soul being acted upon by an external thing (and if perceived, the exciting representation would be subjected to the same critique of veiling the access to the external thing). The soul would play the supporting role to that

\footnotetext{
${ }^{42}$ „Item, aut influxus factus a corpore in spiritu est actio cognitiva aut principium effectivum ipsius aut est actio excitativa potentiae ad actum cognitivum.“ QiniiS 72.24.

43 „Secundo, quia immediatum principium actus essentialiter vivi et cognitivi oportet essentialiter esse vivum et cognitivum; nam essentiam talis actus trahitur et influitur a suo principio immediato. Sed species corporis primo et immediate informans corporale organum non potest esse essentialiter viva et cognitiva. Ergo et cetera." QiniiS 73. 83. See also QiniiS 72, 24-5: „Quarto, quia nihil sic ultimata et actuali ratione habet rationem cognitivi et actus vitalis sicut habet actio cognitiva. Ergo eius effectivum princupium debet esse praestantissimum in genere principiorum cognitivorum et vitalium.“

44 ,principium immediate productivum actus cognitivi non est minus intrinsecum potentiae cognitivae quam ipse actus. Ergo actus cognitivus non poterit immediate gigni a specie corporali existente in organo“. QiniiS 73.83.

45 „Item, aut influxos factos a corpore in spiritu est actio cognitiva aut principium effectivum ipsius aut est actio excitativa potentiae ad actum cognitivum.“ QiniiS 72. 24; see also QiniiS 58. 462; 473-77 and QiniiS 74, 121-22. On this, see José Filipe Silva and Juhana Toivanen: The Active Nature of the Soul in Sense Perception: Robert Kilwardby and Peter John of Olivi. In: Vivarium 48/3-4 (2010). 245-278. 270-73; Toivanen: Perception and the Internal Senses. 135. A similar objection is raised by John Duns Scotus, probably against Henry of Ghent, in Ordinatio I, distinction 3 , pars 3, question 2. In: Opera Omnia. Città del Vaticano: Typis Polyglottis Vaticanis 1954.
} 
external action, not the role of primary and free cause. He confronts this view also with respect to the acts of the will, which some take to be caused by the excitation from the object (excitata ab obiecto). But then the will would ultimately cooperate (cooperari) with a motion originating in the object rather than being free in its action, as the totally active cause of its acts (totaliter activa respectu actuum suorum $).{ }^{46}$ Olivi has no problem in accepting a basic tenet of the Aristotelian account of cognition, namely ,that any apprehension involves the assimilation of cognitive subject to object cognized" but the same cannot be said of the aforementioned tenet that ,the actualization of the power's potentiality requires the action of something else, which is in actuality“ ${ }^{47}$ especially if that actualization is formulated in terms of the so-called species-theory. According to the model that Olivi rejects, the specification of perceptual acts can be explained only with the postulation of these representational devices. ${ }^{48}$

Olivi argues that the object lacks any causal efficacy with respect to cognitive acts: were that the case, the object's action would go beyond the power proper to its corporeal nature ${ }^{49}-$ he makes the same point with respect to the species qua causal agents. ${ }^{50}$ Perception is not the assimilation of sense powers to the forms of material things as the result of the action of such forms because as material (extensa) they cannot be received in such a way that they act upon the simple and spiritual form of the soul. ${ }^{51}$ According to Olivi, it is a mistake to take the action of the object upon the senses as cognitive (or cognitive inducing, as we would say) because a cognitive operation must have as a cause a living principle; in other words, a cognitive act is a vital act (actus vitalis). ${ }^{52}$ For Olivi, then, the action of an object upon the sense organs is cognitively useless because it cannot bring about any cognitive effect on its own: what makes the presence of an object epistemically relevant to a

\footnotetext{
${ }^{46}$ QiniiS 58. 410.

47 ,Aristoteles vero videtur tenuisse quod actus sensuum particularium sint immediate ab obiecto, sicut illuminatio aeris est a sole et motio mobilis a motore. Unde vult quod sentire est quoddam pati“. QiniiS 74. 110.

${ }^{48}$ See e.g. Qiniis 58, 467

${ }^{49}$ Qiniis 72. 101

50 ,impossibile est quod aliquid corporale directe influat in potentias animae“. QiniiS 73. 83.

${ }^{51}$ Qiniis 73.83.

${ }^{52}$ „Quarto, quia nihil sic ultimata et actuali ratione habet rationem cognitivi et actus vitalis sicut habet actio cognitiva.“ QiniiS 72.24-5. On this see Silva: Medieval Theories of Active Perception: An Overview. 117-46. The thesis here is that we have cognitive acts on account of being living beings (see QiniiS 58. 463).
} 
subject is her soul actively attending to the environment. ${ }^{53}$ Therefore, one should accept that the immediate cause of a cognitive operation is an internal principle, which is the soul itself or the soul via its power. ${ }^{54}$

Olivi is also clear in attributing a sense of ownership to the agent: we know (with certitude) that these are acts that originate in us (sentimus esse a nobis) and that the agent is so named because it is that which causes the action rather than the one receiving the action or being acted upon. ${ }^{55}$ Going back to the original claim about the connection between being the principle of life and being the principle of cognition, it would be pointless to attribute those acts that we (intimately, intime) perceive as ours qua living and sensing and understanding creatures to objects and their accidental features. ${ }^{56}$ On the contrary, Olivi suggests, this sense of intimacy with and ownership of our own acts (that is, of ourselves as agents) is constitutive of our identity as living beings and explains the continuous nature of our experience of the world (intima et continua experientia). ${ }^{57}$ Having argued against both the causal model and the excitation model of perception, Olivi must provide an explanation of how the cognitive acts of the soul are directed towards particular things in the world. He does so by assigning the object the role of the end-term of the perceptual experience, the ,that-about-which-the-act-is ${ }^{6}$ and what it tends to. By being the terminative cause (causa

\footnotetext{
53 ,,[potentia cognitiva] non potest in actionem cognitivam exire, nisi prius intendat actualiter in obiectum, ita quod aspectus suae intentionis sit actualiter conversus et directus in illud." QiniiS 72. 9. On this, see Toivanen: Perception and the Internal Senses, especially chapters vi and vii; Silva and Toivanen "The Active Nature"; and Robert Pasnau: Theories of Cognition in the Later Middle Ages. Cambridge 1997.

${ }^{54}$ „Quartus modus est, quando agens agit intra se, dirigendo vim suam activam in obiectum extrinsecum et etiam eo ipso aperiendo et applicando suam potentiam pasivam ad ipsum obiectum, acsi deberet illud obiectum intra se capere. Et hoc modo immediatum principium actionis apprehensivae vel volitivae agit intra potentiam animae." QiniiS 72. 9. See also QiniiS 74. 114: "omnis actus cognitivus vel creditivus efficitur ab ipsa potentia tanquam a vi activa“.

${ }^{55}$ „Secundo, quia nos expresse sentimus nostros actus videndi vel cognoscendi exire seu produci a nostris intimis et hoc intime. “, QiniiS 72. 24. The species generated by the internal senses and kept by memory retain this personal reference: I remember myself hearing (QiniiS 74. 116). See also QiniiS 62. 589: “[...] vita quae sentit se sentire corporalia sentiat etiam se ipsam".

${ }^{56}$ QiniiS 58. 413, 463-64. The implication in the last passage is that this sensing its own acts by sensing that it originates in one's own substance (in Olivi's awkward formulation: „sentit illum actum exire a suo supposito”) is a function of the intellect („Unde ita dicimus per intellectum: ego video vel audio sicut ego intelligo“).

${ }^{57}$ „quia cum quis sentit se scire et videre et amare, ipse sentit tunc identitatem et, ut sic loquar, suitatem sui ipsius, in quantum cognitum et in quantum suppositum activum, ad se ipsum hoc advertentem et sentientem“, QiniiS 74. 126. (See the whole passage on pages 124-126.) See also QiniiS 72. 38: „sentimus quod est actio nostra et quoddam agere nostrum a nobis exiens et quasi in obiectum tendens et in illud intendens“.
} 
terminativa), the object cannot have the role of efficient cause ${ }^{58}$ instead, it suffices that it is present to the subject, ${ }^{59}$ the terminus ad quem of the soul's attention and in this way determining the content of the act of the sensory power. ${ }^{60}$ This also allows him to argue against possible skeptical claims concerning why the soul cannot on its own and by its own power produce an image of an external thing and perceive it: ${ }^{61}$ it requires the presence of the object and by being directed to (and determined by) the object, the perceptual act becomes the likeness of the terminative object. ${ }^{62}$ The cognitive act is the likeness and expression of the object being perceived, by which he means „the proper likeness of this individual insofar as it is of this one“, thus representing ,the individual character and proper quality of its object" ${ }^{63}$ Elsewhere he talks about this determination of content as the objects contracting the cognitive acts to their specific accounts. ${ }^{64}$ This is significant because it means that the aspectual directedness to any one thing is further determined by being about this thing as so and such.

Olivi has succeeded in explaining the determination of the cognitive act by assigning to the object the role of terminative cause, but he leaves unexplained how this is possible. Having stated that there can be no cognitive act without the presence of the object, ${ }^{65}$ and having denied the excitation account, he needs to explain why determination does not entail efficient causation. The way out for

\footnotetext{
${ }^{58}$ QiniiS 72, 10; 36; also QiniiS 58, 414: “Assimilatur igitur actus obiecto tamquam suo intimo termino, non tanquam suo efficienti“".

59 ,ad videndum vero vel audiendum res ubi sunt sufficiet interna directio nostri virtualis aspectus ad ipsas res visas absque aliqua reali emissione suae essentiae“, QiniiS 73, 61. See also QiniiS 74. 122-23: „Primo, quia obiectum praesens aspectui in ipsum converso et intento sufficienter se praesentat ei per semetipsum". If the species were present, then these would be the object of the cognitive act: "quia frustra ponitur species repraesentans obiectum aspectui, nisi aspectus intendat in ipsam“, QiniiS 74, 123.

${ }^{60}$ QiniiS 58, 487. See also QiniiS 73, 103: “mutatio aspectus non ponitur fieri ab obiecto sicut ab efficiente, sed solum sicut a terminante“.

${ }^{61}$ Qiniis 72. 35; Qiniis 58. 469

${ }^{62}$,[potentia cognitiva] nisi prius intendat actualiter in obiectum, ita quod aspectus suae intentionis sit actualiter conversus et directus in illud.“ QiniiS 72. 9. See also QiniiS 58. 473: „Sed actio quae procedit ab anima post aspectum seu conversionem actualem et cum actuali terminatione obiecti est actio cognitionis seu apprehensionis ipsius obiecti.“

${ }^{63}$ „Rursus sciendum quod quia actus cognitivus obiecti individualis est terminatus in ipsum, in quantum est hoc individuum et non alio: ideo de essentia talis actus est quod sit propria similitudo huius individui [...] Quod igitur actus iste repraesentet individualem rationem et proprietatem sui obiecti“ QiniiS 72. 37, transl. Pasnau. In: Forms of Knowing: Theories of Cognition in the Later Middle Ages. PhD Dissertation: Cornell University 1994. Appendix C. Cf. Han Thomas Adriaenssen: Peter John Olivi on Perceptual Representation. In: Vivarium 49 (2011). 324-352. 341-46. ${ }^{64}$,actus cognitivi et volitivi trahant suas rationes specificas ex obiectis“. QiniiS 74. 127.

${ }^{65}$,absque accidentali aspectu in obiectum aliquod actualiter terminato non potest nostra potentia volitiva vel cognitiva aliquem actum cognitivum vel volitivum producere.“ QiniiS 74. 130.
} 
Olivi is to show, like Augustine before him, that the intentional act of the soul, which is determined by the object, is independent and prior to its determination. What is needed is what I have called elsewhere the pre-experiential ,intentional attention“, ${ }^{66}$ which is directed to the world, and which Olivi refers to as ,the virtual reaching out to the external [world]“ (virtualis protensio ad extra: QiniiS 73, 104). So, there is causation in the end but it is the causation of perceptual acts by the soul as the result of its mode of being as vivifying and thus as cognitive principle. This general directedness or ,content-free' attentional nature of the soul provides the condition for perception but needs to be determined by the object as the end point of its cognitive act, so as to be about a particular thing in the world. ${ }^{67}$ The power draws, as it were, the object into itself (intentionaliter habet ipsum intra se imbibitum) by assimilating or configuring itself to this individual thing, which constitutes the cognition (apprehensio) of the thing. But this is possible only because the power generates its own cognitive act; otherwise, if the object were the cause of the cognitive act, the power would not be able to cognize the object as the individual thing it is and as present. ${ }^{68}$

Olivi conceptualizes this distinction in terms of the intentionality of the power being focused into an aspect or look (aspectus suae intentionis) upon a particular thing. ${ }^{69}$ In other words, the aspectus

\footnotetext{
${ }^{66}$ Silva: Medieval Theories. 133. See also QiniiS 58. 466: "Praeterea, si actus non est aliquo modo a potentia nostra tanquam a principio effectivo, sed solum ab ipsis speciebus: ad quid igitur requiritur semper actualis aspectus et quaedam virtualis protensio ipsius potentiae ad obiectum et quidam vehemens conatus ipsius ad intentius et efficatius intelligendum et sentiendum?" (emphasis added). The point seems clear: a cognitive act requires the actual aspect tuned to the object but is preceded by the virtual reaching out of the power and the natural intentionality (of the soul) to perceive (and understand).

67 „Nam actus et aspectus cognitivus figitur in obiecto et intentionaliter habet ipsum intra se imbibitum; propter quod actus cognitivus vocatur apprehensio et apprehensiva tentio obiecti. In qua quidem tentione et imbibitione actus intime conformatur et configuratur obiecto. [...] sic, quia vis cognitiva generat actum cognitivum cum quadam informativa imbibitione actus ad obiectum“. QiniiS 72. 36.

${ }^{68}$ Qiniis 72. 37.

69 „Huius autem positionis impossibilitas infra plenius ostendetur, nunc autem sufficiat dicere quod quantumcunque potentia cognitiva per habitum et species ab actione cognitiva differentes sit informata, non potest in actionem cognitivam exire, nisi prius intendat actualiter in obiectum, ita quod aspectus suae intentionis sit actualiter conversus et directus in illud.“ QiniiS 72.9. See also QiniiS 58. 486 where Olivi uses ,,aspectus suae virtutis“. The suggestion here is that for Olivi aspectus constitutes a special case of psychological intentio, directed to a particular object or terminative cause. It is important to remark that Olivi relates the aspectus of the power and the power's turning-round (conversio) to a particular object as effect and cause respectively (e.g. QiniiS 37. 668; QiniiS 73.64). On aspectus and a slightly different account of the relation between aspectus and intentio, see Toivanen: Perception and the Internal Senses. 15561.
} 
directs the undetermined intention(ality) of the soul to a particular terminal object. ${ }^{70}$ There is a look or aspect to my intentionality, with intentionality being prior to the looking at a particular thing.

This seems harmonious with the interpretation of the Augustinian way of proceeding that I tried to spell out in the first section of this paper. The outlook of this account is that perception is the result of the soul's own agency and that all causal efficacy is denied to the object, except in its role as determinant of the content of the perceptual act (its being about some one thing rather than another). ${ }^{71}$ There is probably a lengthier story to tell about the aspectus and how it seems to be determined in its operation by physiological constraints, for instance by the structure and constitution of the eye,$^{72}$ but this is not the place to tell it.

It is worth emphasizing how Olivi's theory allows us to jump from a restricted Aristotelian view of perception as the result of causally efficacious sensible qualities to alternative accounts of perception that can do without the representational value of species being associated with their causal role, or that even ditch any account of perception based on the existence of external and internal species with a cognitive import. As we have briefly seen, Olivi’s criticism cleverly addresses two main difficulties in the species doctrine: the obscuring of the thing known by means of a veil of representations and, as the result of this, the impossibility of taking for granted the existence of any external thing which should be the object of perception. If we have direct access

\footnotetext{
${ }^{70}$ Toivanen: Perception and the Internal Senses. 183-91, argues that this can be characterized in terms of an aspectus generalis determined by an aspectus determinativus. The problem with the two key passages, quoted in pages $184-85$, is the causal undertone found in both: the presence of the object to the perceiver „necessarily generates“ the act of hearing (184) and causes „a sensation“ (185). In QiniiS 73. 106 Olivi makes clear that any aspectus must be directed to something, i.e. there cannot be an aspectus directed to nothing: „omnis aspectus exigit aliquid pro obiecto, pro eo quod non potest aspective dirigi ad mere nihil“. This applies also to the aspectus of the will (QiniiS 58.415). The point is that it is in the nature/essence of any cognitive or volitional power to realize its act but this realization requires the presence of a (suitable) object; but this shows that some level of activity precedes the particular act directed to that object.

71 ,dico quod actus cognitivi efficiuntur a potentia, non tamen per solam nudam essentiam eius, immo in omnibus exigitur actualis aspectus super obiectum actualiter terminatus.“, QiniiS 74.113.

${ }^{72}$ Qiniis 73, 90-98. In this section of the work, Olivi examines some of the key elements of the tradition of geometrical optics originating in Alhacen and elaborated in Roger Bacon and John Pecham, both his contemporaries. It is, for instance, interesting to notice how he uses arguments for the mode of transmission of the species from the sense organs to the organ of the common sense in order to argue against the existence of species. He does so by showing how the two major alternatives - that the species move in straight lines according to geometrical principles and that the species have a spiritual nature and thus need not obey the laws applied to material things - are deeply flawed (see especially page 98). See also QiniiS 58 (491-93), where he describes the view of those who follow Arabic perspectivist theory (sequentes perspectivam Arabum). See Katherine Tachau: Vision and Certitude in the Age of Ockham. Optics, Epistemology, and the Foundations of Semantics 1250-1345. Leiden 1988. 39-51.
} 
merely to a representation, how would we know that our knowledge of the external world is warranted? The other difficulty, metaphysical in nature, concerns the way in which a material thing would be able to act upon the immaterial human soul.

It is important to notice however that this epistemological concern - but not the metaphysical one also applies to the active theories that accept the existence of mediatory representational devices, the species. In a sense, it doesn't matter for Olivi whether these species have their source in the external thing or in the productive soul: the point is that by conceiving the existence of such entities the theory complicates the story about how we can have direct access to the external world. Instead of focusing on how the species represent and what they represent, our account of perceptual experience should concentrate on the inbuilt capacity of the soul to bring about its cognitive acts on its own. This capacity is justified by the natural directedness of the soul towards the world and independent of, even if determined by, particular objects present to its perceptual reach. Olivi's theory of perception shares with Augustine - at least in the way I have interpreted both - this basic distinction between the two senses of intentionality: the soul is directed towards the world as its mode of being in the body and the cognitive acts of the soul are about the objects that determine them by being their terminative causes.

\section{Conclusion}

The general description of the process of perception as the soul supplying the conditions for perception by its mode of presence in the body and as the efficient cause of its own perceptual acts is defended by both authors discussed in part II. The soul is, in this action, dependent on the external thing to determine its power to an actually present external thing. In Henry, this means the affection of the perceiver's sense organs, whereas in Olivi this seems to require simply that the thing is present to the perceptual field. In the case of the latter, intentionality starts by being a general directedness towards the world in a non-cognitive sense, which is then determined by being 
a relation to a content due to the presence of the external thing. In both cases, however, and against overly dualist interpretations of Augustine, they show a clear commitment to perception as aimed primarily at the soul's preservation and promoting the wellbeing of the instrumental and dearly beloved body. 